\title{
TEOLOGI INKLUSIF NURCHOLISH MADJID: HARMONISASI ANTARA KEISLAMAN, KEINDONESIAAN, DAN KEMODERENAN
}

\author{
Zainal Abidin \\ Character Building Development Center (CBDC), BINUS University \\ Jln. Kemanggisan Ilir III No. 45, Kemanggisan - Palmerah, Jakarta 11480 \\ aby.zie@gmail.com
}

\begin{abstract}
This article is motivated by the phenomenon exists today, that Muslims are no longer perform properly inclusive theology. Religion is expected to bring mercy to all the worlds mission no longer demonstrate their role appropriately. Today most Muslims understand Islam as a doctrinal teachings, exclusive, and opposite with local wisdom and culture of Indonesia. Nurcholish Madjid gives a different idea in understanding Islam. For him, Islam is a modern and inclusive teaching of the other religions and cultures, and countries. Madjid is famous for his ideas about the reform of Islamic thought. According to him, Islam should be involved in the struggles modernistic based on the richness of traditional Islamic thought that have been established, once placed in the context of Indonesian-ness. Methodologically this study uses hermeneutic approach, and methods that is used in the search data is library research.
\end{abstract}

Keywords: an inclusive theology, universalism of Islam, modernity, Indonesian, and secularization

\begin{abstract}
ABSTRAK
Karya ini dilatarbelakangi oleh fenomena yang ada saat ini, bahwa kaum Muslim tidak lagi melaksanakan dengan baik teologi inklusifnya. Agama yang diharapkan membawa misi rahmat bagi seluruh alam tidak lagi menunjukkan peranan secara tepat. Saat ini sebagian kaum Muslim memahami Islam sebagai ajaran yang bersifat doktrinal, eksklusif, dan berseberangan dengan budaya dan kearifan lokal bangsa Indonesia. Nurcholish Madjid memberikan sebuah gagasan yang berbeda dalam memahami Islam. Baginya, Islam adalah ajaran yang modern dan inklusif terhadap agama dan budaya lain, maupun negara. Madjid terkenal dengan gagasannya tentang pembaruan pemikiran Islam. Menurutnya, Islam harus dilibatkan dalam pergulatan-pergulatan modernistik yang didasarkan atas kekayaan khazanah pemikiran keislaman tradisional yang telah mapan, sekaligus diletakkan dalam konteks keindonesiaan. Secara metodologis penelitian ini menggunakan pendekatan hermeneutik (hermeneutics approach), dan metode yang digunakan dalam pencarian data adalah penelitian kepustakaan (library research).
\end{abstract}

Kata kunci: teologi inklusif, universalsime Islam, kemoderenan, keindonesiaan, dan sekulerisasi 


\section{PENDAHULUAN}

Cak Nur panggilan akrab Nurcholish Madjid (selanjutnya disebut Madjid atau Cak Nur) adalah seorang tokoh cendekiawan Muslim Indonesia yang dikenal dengan gagasannya tentang pembaharuan pemikiran Islam. Kehadiran Madjid memang tidak bisa dipisahkan dari kontroversi dan aksi politik keagamaannya dalam sejarah pergolakan dan Islam Indonesia. Keberadaan Madjid dalam wilayah intelektual Indonesia, tidak disangsikan lagi sebagai salah satu pemikir modern dalam wacana pemikiran Islam di Indonesia. Di satu sisi, kehadirannya mampu mendobrak tatanan baru pola pemikiran Islam dengan menghadirkan suasana baru ketika berhadapan dengan teks-teks Islam. Dan di sisi lainnya secara genial dia mampu memadukan gagasan yang ada dalam berbagai tradisi yang berbeda.

Madjid terkenal dengan gagasannya tentang pembaruan pemikiran Islam. Menurutnya, Islam harus dilibatkan dalam pergulatan-pergulatan modernistik yang didasarkan atas kekayaan khazanah pemikiran keislaman tradisional yang telah mapan, sekaligus diletakkan dalam konteks keindonesiaan. Madjid pertama kali menyampaikan ide-ide pembaharuannya secara formal pada 2 Januari 1970 di Jakarta dalam acara halal bilhalal di depan keluarga Himpunan Mahasiswa Islam (HMI), Gerakan Pemuda Islam (GPI), Pelajar Islam Indonesia (PII), dan Persatuan Sarjana Muslim Indonesia (Persami), dengan judul "Keharusan Pembaharuan Pemikiran Islam dan Masalah Integrasi Umat". Bahasannya mencakup: "Islam Yes, Partai Islam No, Kuantitas versus Kualitas, Liberalisasi Pandangan terhadap Ajaran Islam Sekarang” (Sekularisasi, Kebebasan Berpikir, Idea of Progress, dan Sikap Terbuka), dan perlunya kelompok pembaharuan "liberal”.

Pada 5 Februari 1970, dia menyampaikan pidato pada acara HUT ke-3 HMI di Jakarta, dengan judul yang tidak jauh berbeda "Menuju Pembaharuan Pemikiran dalam Islam”. Makalah-makalah tersebut kemudian dilengkapi wawancara dengan Harian Kompas (1 April 1970), yang bahasannya mencakup: Beragama secara Konvensional, Sekularisasi dan Sekularisme, dan Beberapa "Asuhan” dari Agama (al-Qur'an). Pada 30 Oktober 1972, dia memberikan kuliah di Pusat Kesenian Jakarta dengan judul "Menyegarkan Paham Keagamaan di Kalangan Umat Islam Indonesia”, dan beberapa tulisan lainnya yang dimuat dalam Pos Bangsa, Tribun dan Panji Masyarakat (Dewan Redaksi Ensiklopedi Islam, 1994).

Madjid adalah sebuah fenomena yang tidak saja menarik, tetapi juga unik dan membingungkan, baik dalam wacana pemikiran keagamaan (Islam), budaya, maupun politik di Indonesia. Kita sepakat Madjid adalah sosok yang kontroversial. Untuk memahami kontroversi Madjid, bukanlah usaha yang mudah, karena dia selalu melakukan lompatan-lompatan aksi dan pemikiran yang tak lazim di zamannya dalam konteks ke-Indonesia-an, bahkan tulisan-tulisannya pun sangat kompleks dan materinya boleh dikatakan komprehensif, menarik, tajam, dan selalu mengandung gagasan-gagasan cerdas, tetapi tetap saja menyisakan ruang untuk bertanya akibat penulisannya yang singkat dan kadang terkait dengan peristiwa atau wacana yang ngetren saat itu. Tidak mudah untuk memahami sosok Madjid secara utuh. Perlu dilakukan banyak pengamatan dan penelusuran dari berbagai disiplin ilmu.

Dengan tidak menafikan kenyataan tersebut, dengan penuh rasa keserba-kurangan, penulis memberanikan diri sedikit memahami sosok Madjid, tentunya dalam tema yang sedang diteliti. Dalam pandangan penulis, untuk lebih memahami Madjid, pertama kali harus memahami sosok Madjid sebagai orang yang terintegrasi dengan pemikiran dan gerakan NU atau Nahdhah al-'Ulama (Barton, 1999), Masyumi (Madjid, 1995; Malik \& Ibrahim, 1988), dan Muhammadiyah.

Madjid berasal dari kalangan keluarga pesantren, putra seorang guru Madrasah al-Wathaniyah di Jombang, Haji Abdul Madjid, murid dari KH Hasyim Asy’ari. Abdul Madjid adalah salah seorang murid kesayangan KH Hasyim Asy'ari di Pesantren Tebuireng, Jombang. Untuk beberapa tahun 
lamanya ayah Madjid belajar langsung di bawah bimbingan KH Hasyim Asy'ari, bahkan pernah dinikahkan dengan cucu sang guru (setelah cerai menjadi Nyai Kiai Adlan Ali dan Abdul Madjid sendiri kemudian menikah dengan gadis lain atas pilihan sang guru yang melahirkan Nurcholis Madjid). Tidak dapat diingkari bahwa wawasan intelektual Abdul Madjid, yang kemudian mempengaruhi pemikiran Nurcholis Madjid dengan kental, dibentuk oleh guru dan pembimbingnya ini. Dan terutama ketika Abdul Madjid mengikuti KH Hasyim Asy’ari untuk bergabung dalam Masyumi, dan terus bertahan di Masyumi sebagai rasa hormat terdalam pada Sang Guru yang ketika menunggal masih menjadi tokoh Masyumi. Dari ayahnya Madjid terintegrasi dengan pemikiran dan gerakan NU (Barton, 1999).

Adapun pengaruh pemikirin dan gerakan Masyumi terhadap Madjid berawal dari kegagalannya mondok di Pesantren Darul Ulum Rejoso, Jombang. Di Darul 'Ulum Madjid hanya bertahan dua tahun. Ada dua alasan mengapa dia hanya bertahan dua tahun di sana; pertama, karena alasan kesehatan yang kurang menunjang, dan kedua, karena alasan ideologi dan politik. Tampaknya alasan politik yang paling dominan, seperti sudah diketahui pada 1952 NU keluar dari Masyumi dan mendirikan partai sendiri. Ayah Madjid tetap bertahan di Masyumi, dan ini berimbas pada Madjid; dia menjadi bahan ejekan santri-santri di sana. Kemudian dia meneruskan pendidikan ke Kulliyyat alMu'allimin al-Islamiyyah (KMI) di Pesantren Darussalam, Pondok Modern Gontor, Ponorogo, Jawa Timur, sampai tamat 1960 (Madjid, 1995; Malik \& Ibrahim, 1988).

Sedangkan pengaruh Muhammadiyah Madjid dapatkan ketika kuliah jurusan Bahasa dan Sastra Arab, IAIN Syarif Hidayatullah, Jakarta, dia sering berkomunikasi dengan Buya Hamka (tokoh Muhammdiyah) dan menjadi penerjemah bahasa Inggris bagi Buya Hamka ketika ada tamu-tamu dari Eropa atau Amerika. Dari hubungan ini Madjid memahami dan bahkan terpengaruh dengan gerakan Muhammadiyah. Tanpa memahami integritas ini, kita akan kesulitan melihat Madjid sebagai tokoh intelektual Islam yang resah dengan keberadaan umat Islam pada zamannya. Karena lompat-lompatan pemikirannya yang sebenarnya bertujuan untuk memberikan pencerahan dan perbaikan bagi umat Islam. Tapi sebagian umat Islam menolak, bahkan ada yang melihat Madjid sebagai 'perusak Islam' walau hanya terbatas pada kalangan konservatif Islam. Di sinilah letaknya, kenapa harus memahami Madjid secara komprehensif sebagai sosok yang pemikirannya terintegrasi dengan gerakan NU (Nahdhah al-‘Ulama), Masyumi, dan Muhammadiyah.

Selain itu sosok Madjid juga perlu dipahami sebagai figur religius. Untuk itu sangat penting mengapresiasikannya sebagai seorang intelektual, karena hampir tidak mungkin untuk memahaminya secara sepenuhnya, jika tidak menghargai keyakinan agamanya, tanpa penghargaan terhadap sisi intelektual. Tanpa penghargaan terhadap sisi intelektualnya tersebut, kita tidak akan pernah sampai pada pemahaman yang memadai tentang jalan pikirannya.

Dari tulisan-tulisannya di berbagai sumber, terbaca bahwa Madjid sangat kritis terhadap agama (Islam) dan negara. Perjuangannya yang gigih dalam menegakkan pemahaman keislaman, kemoderenan, dan ke-indonesia-an yang di luar kebiasaan umum, telah memposisikannya sebagai guru bangsa. Dalam hal agama, tema yang paling jelas muncul dalam tulisan Madjid adalah bahwa Islam adalah keyakinan yang menebar kasih sayang, yang secara mendasar toleran dan menghargai perbedaan, sekaligus agama keadilan dan kejujuran. Artinya Islam adalah keyakinan yang egaliter, keyakinan yang secara fundamental tidak mendukung perlakuan yang tidak adil, karena alasan kelas, suku, gender, atau pengelompokan-pengelompokan lain dalam masyarakat. (Dale, 2002). Hal tersebut menjadi sebuah alasan untuk memilih Madjid sebagai topik kajian utama dalam tulisan ini.

Berdasarkan latar belakang masalah tersebut, maka yang menjadi masalah pokok dalam tulisan ini adalah: 1) Aspek apa saja yang terdapat pada pemikiran Madjid tentang Islam dan inklusivitas? 2) Bagaimana relevansi pemikiran Madjid tentang Islam dan inklusifitas bagi kehidupan keagamaan di Indonesia di masa mendatang? 
Kajian ini dimaksudkan untuk memberi jawaban atas pertanyaan-pertanyaan pokok di atas, dan apakah gagasan-gagasan pemikiran Madjid tentang Islam dan inklusifitas dapat menjembatani kesenjangan antarumat beragama. Di sisi lain ingin diselidiki kontribusi pemikiran Madjid tentang Islam dan inklusifitas untuk perkembangan ilmu pengetahuan, khususnya pemikiran inklusivisme dan pluralisme Islam demi kemajuan masyarakat Islam pada khususnya dan masyarakat Indonesia pada umumnya.

\section{METODE}

Sebagai suatu analisa-filosofis terhadap pemikiran beberapa tokoh, secara metodologis penelitian ini menggunakan pendekatan hermeneutik (hermeneutics approach). Kata hermeneutik (hermeneutics) berasal dari bahasa Yunani hermeneuin, yang berarti menjelaskan, menerjemahkan dan mengekpresikan. Sumber lain menjelaskan bahwa hermenetik merujuk pada Hermes, seorang utusan Tuhan dalam mitologi Yunani. Tugas Hermes adalah menjelaskan perintah-perintah Tuhan kepada manusia, dengan kata lain dia bertugas menjembatani dunia langit (devine) dengan dunia manusia. Salah satu pendekatan hermeneutik adalah adanya kesadaran mendalam bahwa untuk menangkap sebuah teks tidak bisa hanya mengandalkan pemahaman gramatika kebahasaan, melainkan memerlukan data-data dan imajinasi konteks sosial serta psikologis baik itu si pembicara (pengarang) maupun pendengar (pembaca).

Pendekatan hermeneutik yang akan digunakan dalam penelitian ini adalah hermeneutik gramatikal, hermeneutik historical, dan hermeneutik filosofi. Yang pertama, berfungsi untuk menelusuri segala yang berkaitan dengan kebahasaan sehingga bisa mengartikan teks, kedua, berfungsi untuk mencari sejarah, karya, dan pengarang, sedangkan ketiga, berfungsi sebagai kendali penalaran dari kedua bentuk interpretasi lain (Priyanto, 2001).

Pangkal tolak hermeneutik gramatikal adalah bagaimana suatu ungkapan dalam bahasa tulis atau bahasa tutur yang dipahami dalam situasi hubungan dialogis (Priyanto, 2001). Heurmeneutik memiliki dua aspek, yakni pemahaman dan penjelasan. Aspek pemahaman meliputi pemahaman isi karya, bahasa, dan jiwa pengarang serta jiwa zamannya, dan aspek penjelasan meliputi penjelasan huruf, makna, dan latar belakang pemikiran (Priyanto, 2001).

Untuk mengerti sebuah teks di masa lampau diperlukan hermeneutik historical. Ada dua cara yang harus ditempuh, pertama, si peneliti harus ke luar dari zaman tempat hidupnya sekarang, dan kedua, merekontruksi jaman si pengarang dan menampilkan kembali suasana ketika dia menulis karya tersebut. Dengan kata lain, peneliti harus menyamakan diri dengan "pembaca asli" yang dahulu dituju oleh teks yang bersangkutan, sehingga si peneliti menjadi kawan sejaman dengan si pengarang. Jika itu sudah tercapai, maka melangkah lebih jauh lagi, yakni menyamakan diri si peneliti pada diri si pengarang dengan membayangkan bagaimana pikiran, perasaan, dan maksud si pengarang tersebut. Dengan demikian si peneliti harus pindah ke dalam kehidupan batinnya (Priyanto, 2001).

Untuk melengkapi kedua pendekatan tersebut diperlukan pendekatan hermeneutik filosofi, sudah barang tentu hermeneutik ini tidak hanya melihat secara normatif apa ide-ide tersebut sebagai sebuah kajian ontologis, melainkan juga harus dikaji secara epistimologis dan aksiologi. Dalam terninologi kefilsafatan, secara internal pengetahuan dalam hakekat mengacu pada tiga aspek, yaitu: (1) ontologi, kajian tentang karakteristik-karakteristik esensial wujud dalam dirinya sendiri, terpisah dari kajian tentang hal-hal yang ada secara particular. (2) Epistemologi, kajian tentang asal usul, anggapan dasar, tabiat, rentang, dan kecermatan (kebenaran, keterandalan, keabsahan) pengetahuan. (3) Aksiologi, kajian tentang kemanfaatan, analisis tentang nilai-nilai untuk menentukan makna, karakteristik, asal-usul, jenis, kriteria, dan status epistimologis (Suriasumantri, 1987; Tim Penulis Rosda, 1995). 
Dari tiga kajian tersebut dapat dirumuskan beberapa pernyataan, yaitu, bagaimana ide-ide tersebut bisa muncul, apa latar belakang, dan untuk apa ide-ide tersebut dimunculkan, sebab tidak ada suatu gagasan pun yang dikemukakan oleh seorang tokoh tanpa ada suatu tujuan tertentu. Bahkan perlu diselidiki secara lebih mendalam tentang sejarah hidup, pendidikan, pemikiran-pemikiran yang mempengaruhi, perkembangan pemikiran, dan metodologi pemikiran. Di samping faktor eksternal termasuk bidang ekonomi, politik, sosial, budaya, dan corak pemikiran yang sedang berkembang saat itu.

Metode yang digunakan dalam pencarian data adalah penelitian kepustakaan (library research) dengan cara membaca buku-buku karya Nurcholish Madjid sebagai data primer, dan bukubuku karya pengarang-pengarang lain yang berhubungan dengan materi yang sedang dibahas ini sebagai data sekunder. Dalam menganalisa data dipergunakan analisis isi (content analysis). Analisis di sini dimaksudkan untuk melakukan analisa terhadap makna yang dikandung dalam keseluruhan ide pemikiran Islam inklusif Madjid. Berdasarkan isi-isi yang terkandung dalam ide-ide tersebut dilakukan pengelompokan yang disusun secara logis dan sistematis.

Untuk mencari pandangan al-Qur'an al-Karim dan Hadits Nabi Muhammad S.A.W. mengenai ide-ide tersebut digunakan analisis semantik, yaitu kata-kata kunci yang terkandung dalam poin-poin pemikiran teologi Madjid tersebut ditelaah dengan cara mencari pengertian pokok logis yang terdapat dalam ayat-ayat al-Qur'an yang saling berhubungan (munasabat al-ayat) maupun dalam hadits-hadits Nabi Muhammad S.A.W. Pencantuman ayat-ayat dan hadits-hadits tersebut diharapkan memberikan pandangan utuh dan menyeluruh terhadap teologi inklusif Madjid tersebut.

\section{HASIL DAN PEMBAHASAN}

\section{Universalisme Islam}

Agama Islam diyakini oleh kaum Muslim sebagai ajaran universal, begitu juga dalam pandangan Madjid (1995). Ke-universal-an Islam tersebut didasarkan pada pernyataan Kitab Suci alQur'an bahwa Risalah Muahammad S.A.W. tidak hanya diperuntukkan pada suatu kaum di suatu masa, sebagaimana para nabi/rasul sebelumnya, tetapi berlaku untuk seluruh alam, termasuk seluruh umat manusia dari berbagai ras dan bangsa. Allah SWT menjelaskan: "Kami (Allah) tidak mengutus engkau (Muhammad), melainkan untuk seluruh umat manusia, sebagai pembawa kabar gembira dan pemberi peringatan" (QS Saba/34: 28). "Tidaklah Kami (Allah) mengutusmu (Muhammad), melainkan sebagai (pembawa) rahmat bagi semesta alam” (QS al-Anbiya/21: 107).

Keseluruhan isi Kitab Suci al-Qur'an begitu juga dengan kedua ayat dari firman Allah tersebut, sangat diyakini kebenarannya oleh seluruh kaum Muslim. Yang menjadi masalah, di manakah letak keuniversalan Islam tersebut? Apakah untuk mendapatkan rahmat dari Muhammad S.A.W. dan Islam harus memeluk Agama Islam (secara formal)? Padahal, keyakinan keagamaan bukan sesuatu yang dapat dipaksakan, tetapi datang dari nurani yang paling dalam. Untuk keperluan tersebut, maka Madjid memberikan beberapa rumusan, di antaranya: Terlebih dahulu harus dipahami apa yang dimaksud dengan Pesan Tuhan. Bagi kaum Muslim, Pesan Tuhan tidak hanya kitab suci alQur'an al-Karim, tetapi juga kitab-kitab suci yang diwahyukan kepada nabi/rasul sebelum Muhammad S.A.W. Di antara Pesan Tuhan yang sering sekali diungkapakan oleh al-Qur'an al-Karim misalnya tentang ketakwaan (at-taqwa), seperti dalam ayat: "Telah Kami perintahkan kepada orang yang diberi al-Kitab sebelum kamu, dan (juga kepada) kamu supaya taqwa kepada Allah” (QS al-Nisa/4: 131).

Menurut Madjid, ayat di atas menegaskan bahwa perintah Tuhan itu sama, baik untuk umat Nabi Muhammad S.A.W. maupun juga untuk umat para nabi/rasul yang menerima kitab suci sebelum Nabi Muhamad S.A.W., yaitu pesan untuk selalu bertaqwa kepada Allah (Madjid, 1995). Makna taqwa di sini sebagaimana dijelaskan olehnya, bukan sekedar "sikap takut kepada Tuhan" atau "sikap 
menjalankan perintah-Nya dan menjauhi larangan-Nya", tetapi lebih menyangkut wacana "Kesadaran Ketuhanan" (consciousness of Godness), yaitu kesadaran tentang adanya Tuhan Yang Maha Hadir (omnipresent) dalam kehidupan sehari-hari (Madjid, 1995). Implikasi kesadaran ini menyangkut kesediaan untuk menyesuaikan diri dengan nilai-nilai Ketuhanan (God-consciousness) tersebut. Taqwa dalam pengertian tersebut, menurutnya adalah sejajar dengan pengertian rabbaniyyah (semangat ketuhanan), yang meliputi "sikap-sikap pribadi yang secara bersungguh-sungguh berusaha memahami Tuhan dan mentaati-Nya” (Munawar-Rahman, 2001).

Pesan taqwa ini sangat universal, dan merupakan kesamaan esensial pesan Tuhan pada manusia yang disampaikan oleh para nabi/rasul untuk setiap bangsa dan masa. Kesamaan di sini bukan kesamaan pokok-pokok keyakinan, akan tetapi kesamaan pesan dasar (agama) yang oleh al-Qur'an sendiri disebut washiyyah (QS al-Syura'/42: 13). yaitu perintah untuk menegakkan agama, yang esensinya adalah paham Ketuhanan Yang Maha Esa (tauhid) (Munawar-Rahman, 2001), dan dalam pandangan Islam merupakan inti semua ajaran para nabi/rasul.

Kesadaran Ketuhanan (taqwa) yang bersifat monoteistik (tauhid), adalah implikasi langsung dari Islam itu sendiri (yang secara generik berarti "sikap pasrah") dan kemudian menjadi nama agama Muhammad S. A. W. Sesungguhnya agama (Arab: al-din, secara harfiah antara lain berarti "ketundukan", "kepatuhan", dan "ketaatan") yang sah tidak bisa lain daripada sikap pasrah pada Tuhan-al-islam (Madjid, 1995; Madjid, 1997). Hendaknya seseorang memasrahkan diri dan kalbunya kepada Allah, dan memurnikan sikap tunduk-patuh hanya kepada-Nya. Itulah al-islam, firman Allah, "Sesungguhnya ikatan (al-din) di sisi Allah adalah sikap pasrah (al-islam)” (QS Alu 'Imran/3: 85).

Dalam pandangan Madjid, al-islam sebagai sikap pasrah dan tunduk-patuh kepada Allah SWT, Sang Maha Pencipta adalah pola wujud (mode of existence) seluruh alam semesta, termasuk manusia, para nabi/rasul pun mengajak kaumnya untuk pasrah dan tunduk-patuh kepada Tuhan (Islam), sebagaimana juga alam semesta.

Dalam al-Qur'an al-Karim dijelaskan bahwa seluruh nabi dan rasul, dari Adam a.s. sampai Muhammad S.A.W. membawa risalah yang 'sama' yaitu islam. Adam a.s. adalah islam (QS al-Syura' [42]: 13, al-Baqarah [2]: 136). Nuh a.s. adalah islam (QS Yunus [10]: 71-72). Ibrahim a.s. adalah islam (QS al-Baqarah [2]: 130-131, Ali 'Imran [3]: 67, al-Hajj [22]: 78). Ya'qub a.s. adalah islam (QS al-Baqarah [2]: 132-133). Yusuf a.s. adalah islam (QS Yusuf [12]: 101). Musa a,s, adalah islam (QS Yunus [10]: 84). Sulaiman a.s. adalah islam (QS al-Naml [27]: 29-31, 44). Isa a.s. dan sahabatsahabatnya adalah islam (QS Ali 'Imran [3]: 52). Dan begitu juga Muhammad S.A.W. adalah islam (QS al-Ma'idah [5]: 3).

Yang membedakan antara mereka hanyalah dalam syariatnya saja. Sikap pasrah dan tundukpatuh kepada Tuhan (al-islam) inilah yang dijadikan sebagai kalimatun sawa', (common platform), antar berbagai keyakinan dan kepercayaan, dan juga sebagai titik tolak pandangan tentang kesatuan kenabian (wahdat al-nubuwwah, the unity of propechy) dan kesatuan kemanusiaan (wahdat alinsaniyyah, the unity of humanity), yang berangkat dari konsep kemahaesaan Tuhan (wahdaniyyah/tauhid, the unity of God) (Munawar-Rahman, 2001). Karena Tuhan telah mengutus rasul/nabi pada setiap bangsa dan masa dalam bahasa yang dimengerti oleh kaumnya (lihat QS anNisa/4: 164, Ibrahim/14: 4). Di sinilah terletak keuniversalan ajaran Islam. Dengan mengutip Ibnu Taimiyyah, Cak Nur menjelaskan, bahwa semua nabi dan rasul adalah sama dan satu yaitu islam, meskipun syari'atnya berbeda-beda, sesuai dengan zaman dan tempat khusus masing-masing nabi dan rasul tersebut (Madjid, 2002). Oleh karena itu Madjid membedakan Islam menjadi dua, yaitu Islam Khusus dan Islam Umum. Islam Khusus adalah Islam yang disampaikan oleh Nabi Muhammad S.A.W. dan kemudian menjadi agama resmi Muhammad. Islam Umum adalah Islam yang disampaikan oleh seluruh nabi/rasul dari Adam sampai Muhammad. Tentang adanya pengertian tersebut Madjid menjelaskan mengutip dari Ibnu Taimiyah: 
“...Orang berselisih tentang umat terdahulu, seperti umat (Nabi) Musa dan umat (Nabi) Isa, apakah mereka itu orang-orang Muslim (muslimun, para penganut al-Islam) atau tidak? Ini adalah perselisihan kebahasaan. Sebab "Islam Khusus" (al-Islam al-Khashsh) yang dengan itu Allah mengutus (Nabi) Muhammad S.A.W. dan yang meliputi syari'at al-Quran tidak ada yang berada di atasnya kecuali umat Muhammad S. A. W. dan "Islam" pada saat sekarang secara keseluruhan berlaku hanya untuk ini. Sedangkan "Islam Umum” (al-Islam al'Amm) yang berlaku untuk setiap syari' at yang dengan itu Allah bangkitkan seorang nabi maka ia berlaku untuk Islamnya setiap umat yang mengikuti salah seorang nabi. Pangkal Islam itu secara mutlak ialah persaksian bahwa tiada Tuhan selain Allah, dan dengan persaksian itulah semua rasul dibangkitkan, sebagaimana difirmankan oleh Allah Ta’ala, "Sungguh telah Kami (Allah) bangkitkan untuk setiap umat seorang rasul (mereka menyeru), Sembahlah olehmu semua Allah (Tuhan Yang Maha Esa) saja, dan jauhilah (lawanlah) kekuatan jahat (thaghut, kekuatan tiranik)”, (QS al-Nahl/16: 36), dan firman Allah Ta’ala, “Tidaklah Kami (Allah) mengutus seorang Rasulpun sebelum engkau (Muhammad) melainkan Kami wahyukan kepadanya bahwa tiada Tuhan selain Aku, karena itu sembahlah olehmu semua (wahai umat manusia) akan Daku saja”, (QS al-Anbiya/21: 25). (Ibn Taymiyah, Al-Risalat alTadammuriyah, al-Qahirah, al-Mathba’at al-Salafiyah, 1387 H, h. 55)” (Nurcholish Madjid, 1995: 224).

Bagi Madjid, ketika al-Quran menyebut Islam bersamaan dengan penyebutan istilah iman dan ihsan, maka pengertiannya sebagaimana dijelaskan dalam Hadist Jibril (Nafis dalam Sukandi A.K. (ed.), 2003). Ketiga nilai keagamaan itu (Islam, Iman, dan Ihsan), itulah Islam dalam pengertian Islam khusus, yang hanya dianut oleh orang-orang yang mempercayai Risalah Muhammad S.A.W. dan Islam inipun merupakan kelanjutan dari Islam Umum. Namun lain halnya ketika al-Quran menyebut alIslam secara sendirian (bi al-tajrid), tanpa berbarengan dengan penyebutan Islam, iman, dan ihsan. Memiliki makna sebagai sikap tunduk dan berserah diri kepada Tuhan dengan tulus (Nafis dalam Sukandi (ed.), 2003). Seperti ketika Madjid mengartikan ayat, "Innad-dina 'indal-lahil-islam." Berbunyi, "Sesungguhnya agama bagi Allah ialah sikap pasrah kepada-Nya (al-islam)" (Madjid, 1995: 9) sesuai dengan firman Allah dalam QS Alu 'Imran/3:19. Demikian juga ketika mengartikan ayat, "Wa man yabtaghi ghairal-islama dinan falan yuqbalu minhu wa huwa fil-akhirati minalkhasirin." Berbunyi, "Barangsiapa menganut selain al-Islam (sikap tunduk dan pasrah tersebut) sebagai agama, maka tidak akan diterima dari dia, dan di akhirat dia akan termasuk orang-orang yang merugi” (Madjid, 1995) sesuai dengan firman Allah QS Alu 'Imran/3: 85.

Agama/sikap keagamaan yang benar (diterima Tuhan) ialah sikap pasrah. Perkataan "alislam" dalam pandangan Madjid pada kedua firman Tuhan tersebut bisa diartikan sebagai "Agama Islam" seperti yang umum dikenal, yaitu agama yang dibawa oleh Nabi Muhammad S. A. W. Pengertian seperti itu benar, dalam maknanya bahwa memang agama Muhammad adalah agama ”pasrah kepada Tuhan” (islam) par excellence (Madjid, 1995). Tetapi selain makna tersebut, Madjid pun mengartikan perkataan al-islam secara lebih umum, yaitu menurut makna asal atau generiknya, yaitu "pasrah kepada Tuhan", suatu semangat ajaran yang menjadi karakteristik pokok semua agama yang benar (Madjid, 1995). Inilah dasar pandangan dalam al-Quran yang oleh Madjid dijadikan sebagai tolak ukur pemahaman bahwa semua agama yang benar bernapaskan Islam, dalam pengertian semuanya mengajarkan sikap pasrah kepada Tuhan.

Pembedaan Islam Khusus dan Islam Umum, bukan untuk menafikan kebenaran Islam (Islam Khusus) yang selama ini dipegang teguh oleh mayoritas kaum Muslim. Sebenarnya Madjid ingin menunjukkan bahwa Islam adalah ajaran universal, Islam tidak pernah dan tidak akan memonopoli kebenaran dan keselamatan, karena itu adalah hak Allah. Semua agama dalam pandangan Madjid memiliki nilai-nilai kebenaran, dan para penganutnya akan memperoleh keselamatan dari Tuhan, asalkan mereka berserah diri, tunduk-patuh (al-islam) pada-Nya. Dalam kerangka ini, Madjid sama sekali tidak mau merelatifkan agama Islam. Justru dia ingin mendudukkan agama Islam pada tempat yang tertinggi. Frans Magnis-Suseno menjelaskan, bahwa pertimbangan teologis itu sangat mendalam dan memperkuat dasar toleransi positif karena memungkinkan bagi umat beragama dengan tenang 
melihat orang lain dalam kelainan kepercayaannya tanpa merelatifkan kepercayaan kita sendiri (Magnis-Suseno dalam Sukandi (ed.), 2003).

Walaupun Madjid beranggapan bahwa ada jalan kebenaran dan keselamatan asalkan berserah diri dan tunduk-patuh kepada Tuhan di luar Islam Khusus, namun Madjid tetap meyakini Islam Khusus-lah yang terbaik. Manusia menurutnya, sebagaimana mengutip Ibnu Rusyd, mempunyai kewajiban moral untuk memilih tingkat perkembangan yang paling akhir, dan Islam Khusus sebagai tingkat paling akhir dari agama-agama dunia ini. Dia menjelaskan:

\begin{abstract}
"Jadi suatu agama, seperti seperti agama yang dibawa oleh Nabi Muhammad (yang memang secara sadar dari semula disebut agama sikap pasrah sempurna kepada Allah atau alIslam), adalah tidak unik (dalam arti, tidak berdiri sendiri dan terpisah), dia berada dalam garis kelanjutan dengan agama-agama lain. Hanya saja, seperti halnya dengan semua yang hidup dan tumbuh, agama itu pun, dalam perkembangan sejarahnya, juga berkembang dan tumbuh, sehingga akhirnya mencapai kesempurnaan dalam agama Nabi Muhammad, Rasul Allah yang penghabisan, yang tiada lagi rasul sesudah beliau. Maka, seperti Ibn Rusyd dalam bagian akhir kitabnya, Tahafut al-Tahafut, meskipun pada esensinya semua agama itu sama, namun manusia pada zaman tertentu mempunyai kewajiban moral untuk memilih tingkat perkembangan yang paling akhir saat itu. Dan perkembangannya yang paling akhir saat itu ialah agama Nabi Muhammad.” (Madjid, 2002).
\end{abstract}

Jika Islam dipahami sebagai ajaran universal, maka hal itu tidak saja menghasilkan pandangan bahwa ia berlaku untuk semua tempat dan waktu. Logikanya ialah, jika Islam itu ajaran universal, dan jika keuniversalannya menghasilkan diutusnya rasul-rasul untuk setiap bangsa dan masa dalam bahasa yang dimengerti oleh kaumnya, sebagaimana telah dijelaskan di atas, maka berarti bahwa kebenaran juga dapat ditemukan pada setiap bangsa dan masa, kapan saja dan di mana saja, dalam bahasa dan budaya yang beraneka ragam pula, sebagai warisan para utusan Tuhan yang pernah datang ke bangsa yang bersangkutan.

\title{
Keislaman, Kemoderenan, dan Keindonesiaan: Keharusan untuk Sekularisasi
}

Nurcholish Madjid dikenal sebagai seorang tokoh kontroversial, karena gagasan-gagasan yang dilontarkannya merupakan gagasan baru dan menggunakan istilah baru pula, sehingga mengundang polemik. Oleh karena itu, dia banyak dikecam baik oleh teman-temannya sendiri maupun tokoh-tokoh lain yang lebih senior. Apalagi dengan gagasannya seperti sekularisasi yang tampaknya masih asing bagi kalangan muslim Indonesia. Predikat "Natsir muda” yang selama ini disandangnya akhirnya dicopot, bahkan dia diituduh sebagai agen westernisme.

Gagasan-gagasan Madjid merupakan pemikiran baru yang lebih bersifat mengelaborasi pemikiran-pemikiran Islam dalam hubungannya dengan masalah modernisasi sosial-politik kaum muslim Indonesia kontemporer. Dan apabila diamati secara seksama, pemikiran Madjid pada dasarnya merupakan dialektika dari tiga ide dalam kesatuan yaitu Islam, kemodernan, dan keindonesiaan. Kesatuan tiga ide ini mirip dengan judul bukunya, Islam, Kemoderan, dan Keindonesiaan, yang diterbitkan oleh Mizan dan buku lainnya, Islam, Doktrin, dan Peradaban: Sebuah Telaah Kritis tentang Masalah Keimanan, Kemanusiaan, dan Kemoderan, yang diterbitkan oleh Paramadina.

Modernitas yang didefinisikan sebagai way of life (jalan hidup) industrial dan urban, khususnya berpihak kepada susunan konsep Barat yang berakar pada abad kesembilan belas; sementara modernisme didefinisikan sebagai "perkembangan dalam seni dan sastra yang menangkap esensi jalan hidup”. Modernitas juga melahirkan sebuah periodisasi baru sejarah (kuno, abad pertengahan, dan modern) di mana modern mendetonasikan periode ketika akal dan ilmu pengetahuan lebih tinggi di atas kitab suci, tradisi, dan kebiasaan. Penyebutan zaman sekarang sebagai zaman modern, oleh Madjid dianggap sebagai konvensi (yang salah kaprah) harus diterima saja, namun, ditilik dari hakikatnya, zaman sekarang akan lebih tepat jika disebut sebagai zaman teknik (technical 
age), "karena, pada munculnya zaman itu adanya peran sentral teknikalisme serta bentuk-bentuk kemasyarakatan yang terkait dengan teknikalisme itu” (Madjid, 2002).

Definisi tersebut, tidak menghindari kemungkinan jenis modernitas lain yang telah ada sebelum sejarah modern, dan juga tidak mengklaim terbatas bagi Barat. Modernitas, bagi Madjid adalah sebuah konsep universal dan selalu dihubungkan dengan ruang dan waktu. Apa yang dianggap modern dalam ruang dan tempat tertentu, yang sudah dilewati selama bertahun-tahun akan menjadi klasik atau kuno. Ini terjadi baik dalam sastra, seni, musik maupun filsafat dan ide. Padahal, dari sudut hakikatnya, zaman modern sesungguhnya bernilai netral saja. Dan perkataan modern mengisyaratkan penilaian tertentu yang cenderung positif (modern berarti maju dan baik), padahal, dari sudut hakikatnya, zaman modern sesungguhnya bernilai netral saja (Madjid, 2002). Inti modernitas adalah konsep kebebasan bertindak, kebebasan pengetahuan individual yang eksperimen-eksperimennya bisa mempenetrasi rahasia alam dan kerja bersama dengan individu-individu lainnya agar bisa membuat dunia baru lebih baik” (Zayd, 2003). Senada dengan itu, mengutip rumusan Lucian W. Pye, Madjid menjelaskan: "... It is based on advanced technology and the spirit of science, on a rational view of life, a secular approach to social relations, a feeling for social justice in public affairs, and above all else, on the acceptance in the political realm of the bilief that the prime unit of the polity should be nation-station.” (Madjid, 1992).

Dari perspektif sejarah kemanusiaan, kemoderenan bukanlah monopoli suatu tempat atau manusia tertentu. Selalu ada kemungkinan bagi tempat-tempat atau kelompok-kelompok manusia lain untuk mengejar dan menyertainya (Madjid, 1994). Lebih-lebih lagi bagi dunia Islam, kemodernan itu semestinya tidak terlalu asing dalam tinjauan kemanusiaan dan intelektualnya. Kemodernan dalam banyak hal merupakan pengembangan lebih lanjut nilai-nilai yang ada dalam tradisi kerohanian IranoSemitik, yang memuncak dalam Islam (Madjid, 1994). Kenyataan ini memungkinkan seseorang mengatakan tentang modernitas, atau lebih modern, sebagai sebuah istilah yang diaplikasikan bagi pemikiran Islam klasik. Namun tepat kalau mengatakan Islam telah membawa modernitas kepada dunia di abad ketujuh dan abad-abad selanjutnya, sebelum modernitas Barat.

Tidaklah berlebihan apabila Madjid mengatakan bahwa Islam adalah yang paling dekat dengan modernitas. Hal ini terutama disebabkan oleh ajaran Islam tentang universalisme, skriptualisme, dan sistematisasi rasional kehidupan sosial (Madjid, 1992). Sesuatu yang paling mendasar untuk menempatkan pesannya sebagai pesan yang paling tinggi, final dan sangat sempurna dalam hubungannya satu sama lain, Islam merekontruksi semua narasi lisan kuno. Dalam hal ini Madjid menempuh jalan skriptualisme untuk kegairahan dalam menjaga kemurnian dan keaslian kitab (Madjid, 1994). Maka, Islam itu modern karena dalam konteks sejarah dan sosialnya memperkenalkan sebuah solusi bagi situasi sosio-sejarah kritis jazirah Arab pada saat itu. Modernisme merupakan bukti pada level kepercayaan, etika, dan sosiologi.

Misalnya, pada level kepercayan, Islam menghadirkan konsep transenden ke-esa-an Tuhan sebagai pengganti bagi kesalehan kepada kesukuan, yakni kepada berhala; dengan melakukan hal itu, Islam membebaskan individu dari penyembahan objek yang dibuat manusia. Dalam konteks sosiologi, orang-orang yang beriman diciptakan untuk menggantikan tatanan sosial yang berdasarkan atas kesukuan. Sementara dalam bidang etika, perilaku bermusyawarah secara individual menggantikan komitmen absolut tribalisme (Islam menyebutnya sebagai jahiliyyat). Selanjutnya, keadilan sosial diperkenalkan dalam bentuk memberikan zakat dan perintah untuk memperlakukan budak-budak secara adil, bahkan memerdekakannya. Kontribusi intelektual Islam terdiri dari mendesak kepada kebebasan berpikir dan refleksi rasional serta secara simultan mengutuk "mengikuti tradisi" atau meniru masa lalu "secara membabi buta (taklid). Selain semua pembaharuan ini, Islam juga mengintegrasikan sistem institusi sosial dan agama yang telah tegak kokoh sebelum kelahirannya, seperti haji, haji ke Mekkah dan Ka'bah yang pada awalnya merupakan rumah berhala, dan berubah menjadi rumah Tuhan. Dalam konteks ini, masjid dan bukan Ka'bah (merupakan sebuah tempat pertemuan para pemimpin suku, dar al-nadwat) secara bertahap menjadi tempat ibadah Muslim. 
Dari sekian banyak karakter/sifat agama Islam yang mendukung kaum Muslim memasuki kehidupan modern ialah seperti diisyaratkan oleh Madjid, bahwa varian murni Islam selalu bersifat egalitarian dan bersemangat keilmuan (scolarly), sedangkan varian yang mengenal sistem hirarkis, seperti terdapat dalam kalangan kaum sufi, selamanya dipandang sebagai berada di pinggiran (Madjid, 1994). Kiranya cukup beralasan untuk mengajukan harapan, seperti yang dikutip Madjid, dari apa yang pernah didendangkan oleh pujangga-filsuf, Muhammad Iqbal, bahwa kaum Muslim dapat tidak saja menyertai Abad Modern, tetapi juga memberi sumbangan positif yang bisa menjadi tanda zaman untuk kemanusiaan abad mutakhir ini dan melengkapi segala kekurangannya (Madjid, 1994). Dan nampaknya segi kekurangan paling serius daripada Abad Modern ialah dalam hal yang menyangkut diri kemanusiaan yang paling mendalam, yaitu dalam bidang kerohanian atau keagamaan (Madjid, 1994).

Islam bukan hanya alat yang menjadi ideologi pemahaman atau penjelasan dunia, atau sekedar keyakinan spiritual belaka; namun secara bertahap Islam menekankan sifatnya sebagai sebuah ideologi bagi perubahan dunia. Madjid menjelaskan:

"Pola itu, dalam tarikan garis ekuasinya, menunjukkan adanya kesejajaran antara Islam dalam modernitas. Pengamatan itu membawa kita kepada renungan lebih lanjut. Jika Islam memang sebuah modernitas seperti dikatakannya, maka seharusnya zaman moderen akan memberi kesempatan kepada kaum Muslim untuk melaksanakan ajaran agamanya secara lebih baik, dan menjadi modern dapat dipandang sebagai penyiapan lebih jauh infrastruktur sosial guna melaksanakan ajaran Islam secara sepenuhnya. Atau zaman modern tentunya akan melengkapi kaum Muslim untuk lebih baik memahami ajaran agamanya dan menangkap makna ajaran itu sedemikian rupa sehingga “api-nya” dapat bersinar lebih terang dalam kegelapan zaman modern di Barat yang ditandai dengan pertentangan antara ilmu dan agama (di sana) yang tak terdamaikan” (Madjid, 1994).

Sebagaimana kaum muslim klasik telah dengan bebas menggunakan bahan-bahan yang datang dari dunia Hellenis namun tanpa mengalami Hellenisasi, Madjid pun menekankan agar kaum Muslim saat sekarang juga dapat menggunakan bahan-bahan modern yang datang dari Barat tanpa mengalami pembaratan atau westernisasi (Madjid, 1992). Dan kalaupun ada penolakan kaum Muslim terhadap modernisasi, bukan karena modernisasi itu sendiri, hal ini disebabkan dendam sejarah. Madjid menjelaskan, sejarah permusuhan itu membuat sebagian kaum Muslim (tidak hanya Timur Tengah) mempunyai semacam naluri untuk menolak modernisasi (Madjid, 1997). Memasuki dan ikut serta dalam abad modern, bukanlah persoalan pilihan, melainkan satu keharusan (Madjid, 1994), bahkan merupakan historical necessity (keharusan sejarah). Dengan cara ini, Madjid nampaknya ingin menumbuhkan rasa percaya diri yang besar kepada kaum Muslim dalam memberikan respon terhadap modernisasi Barat.

Menurut analisa Ernest Gellner, di antara berbagai agama yang ada, Islam adalah satu-satunya agama yang mampu dan tanpa gangguan doktrinal mempertahankan sistem keimanannya pada abad modern ini (Madjid, 1994). Begitupun seharusnya dengan kaum Muslim. Senada dengannya, maka Madjid pun memotivasi semangat modernisasi Islam. Bagi Madjid, makna modernisasi berarti merombak pola pikir dan tata kerja yang tidak aqliah dan menggantinya dengan yang aqliah, karena Tuhan memerintahkan manusia menggunakan akalnya. Modernisasi merupakan perintah dan ajaran Tuhan Yang Maha Esa. Dengan kata lain, sebagaimana dijelaskan M. Dawam Raharjo, modernisasi Madjid adalah obsesi untuk menjelaskan kaitan antara cita tauhid di satu sisi, dan persoalan dunia modern di lain sisi.

Karena kemodernan mengisyaratkan penilaian tertentu yang cenderung positif dan mengharapkan dunia lebih baik. Maka, modernisasi Islam yang dilakukan Madjid berbeda sekali dengan modernisasi yang dilakukan para modernis Muslim dari kalangan konservatif, yang terjebak dalam ideologi-ideologi modern dan kurang perhatian terhadap khazanah Islam klasik. Di sini, Madjid justru sangat menekankan perlunya apresiasi terhadap tradisi dan intelektual klasik Islam yang kaya 
dimensi, sambil menggunakannya untuk memperkaya wawasan intelektual Islam yang baru dengan semangat modernisasi. Jargon klasik kalangan ulama yang terkenal dan sering dikutip Madjid, yakni "al-muhafazah 'ala al-qadim al-salih wa al-akhdzu bi al-jadid al-aslah”, memelihara yang lama yang baik dan mengambil yang baru yang lebih baik (Madjid, 1994). Dalam konsep ini, Madjid menegaskan bahwa sekalipun nilai-nilai dan ajaran Islam bersifat universal dan identik dengan kemoderenan, namun pelaksanaan ajarannya menuntut pengetahuan dan pemahaman tentang lingkungan sosio-kultur masyarakat Indonesia secara keseluruhan, termasuk di lingkungan politik dalam kerangka konsep nation-state (negara-bangsa) dan kemoderenan. Apresiasinya ini secara nyata ditunjukkan dengan menyusun dan menyunting buku, Khasanah Intelektual Islam, dengan memberikan kata pengantar yang elaboratif mengenai warisan intelektual Muslim klasik dan tinjauan tentang modernisme Islam.

Melihat kenyataan ini, Madjid mengatakan bahwa setiap langkah melaksanakan ajaran Islam di Indonesia harus diperhitungkan kondisi sosial budaya yang ciri utamanya adalah pertumbuhan, perkembangan, dan kemajemukan (Madjid, 1992). Dengan demikian untuk perkembangan dan pertumbuhan masa depan Indonesia, kaum Muslim sebagai mayoritas diharapkan memberikan kontribusi sesuai dengan posisi dan jumlahnya. Untuk dapat memenuhi harapan itu, Madjid mengharapkan kaum Muslim mempunyai historical consiousness (kesadaran historis). Tidak dimaksudkan agar Islam dijadikan sebagai satu-satunya sumber nilai dan budaya, tetapi ini sematamata karena Muslim sebagai mayoritas bangsa ini. Mau atau tidak mau pengaruhnya akan lebih terasa daripada yang lainnya.

Menurut Cak Nur, modernitas adalah sebuah konsep universal yang selalu dihubungkan dan dibentuk oleh ruang dan waktu. Karena itu, ketika pemerintah Orde Baru sedang mencanangkan era pembangunan yang berparadigma modern dan Barat, kebijakan ini disambut gembira oleh lingkungan kelas menengah kota yang tergolong secular modernizing intellectual. Sebaliknya kalangan Muslim modernis, terutama para tokoh seniornya justru ragu-ragu bahkan apologis dengan menolak modernisasi karena dinilai sebagai westernisasi atau sekularisasi (Anwar dalam Sukandi [ed.], 2003). Karena itu, Madjid menyayangkan sikap mereka yang jatuh ke dalam perangkap fundamentalisme, menjadi fanatik anti barat, dan bersikap selektif dalam menafsirkan ayat-ayat al-Qur'an. Justru seharusnya kaum Muslim Indonesia menjadikannya untuk memperkokoh pemahaman keislamannya sebagaimana para ulama klasik telah menjadikan Hellenisme sebagai sarana untuk kemajuan peradaban Islam di masa Dinasti Umayyah dan Dinasti Abbasiyyih. Tetapi tetap harus memperhitungkan keindonesiaan. Dan sekularisasinya merupakan respon terhadap nilai-nilai duniawi yang telah disakralkan.

Sekularisasi menurut Madjid bukanlah sekularisme sebagaimana penerapan sekularisme dengan konsekuensi penghapusan kepercayaan pada Tuhan. Madjid pun tidak bermaksud menerima paham sekularisme. Dia mengatakan:

"Sekularisasi tidaklah dimaksudkan sebagai penerapan sekularisme, sebab secularism is the name for an ideology, a new closed world view which function very much like a new religion (sekularisme adalah istilah untuk sebuah ideologi, sebuah pandangan dunia baru yang tertutup, yang berfungsi mirip agama). Dalam hal ini yang dimaksudkan adalah setiap bentuk perkembangan yang bersifat membebaskan. Proses pembebasan ini diperlukan karena umat Islam, akibat perjalanan sejarahnya sendiri, tidak sanggup lagi membedakan nilai-nilai yang disangkanya Islam itu, mana yang transendental dan mana yang temporal” (Madjid, 1987).

Sekularisasi Madjid adalah sekularisasi yang bersifat sosiologis, dan bukan filosofis yang disemangati oleh penafisiran Kitab Suci secara kontekstual model Khalifah II, Umar ibn al-Khaththab. Dia menjelaskan: 
"Setelah menguasai tanah pertanian subur di negeri-negeri yang baru dibebaskan, Umar tidak membagi-bagi tanah itu kepada tentara Islam pembebas seperti yang dikehendaki banyak orang yang terlibat (yang berpandangan begitulah semestinya menurut Kitab Suci), tetapi kepada para petani penggarap dari kalangan rakyat setempat, sekalipun mereka belum, dan tidak menjadi Islam ..., pada keteladanan Khalifah Umar, terdapat pembahasan tentang semangat dari apa yang kelak saya maksudkan sebagai sekularisasi, yang pengertiannya selalu saya tegaskan bersifat sosiologis, bukan filosofis” (Madjid dalam Pardoyo, 1996).

Lebih lanjut Madjid menjelaskan, bahwa sekularisasi tidaklah dimaksudkan sebagai penerapan sekularisme dan mengubah kaum muslimin menjadi sekularis. Namun ini lebih dimaksudkan untuk "menduniawikan nilai-nilai yang semestinya bersifat duniawi“, dan melepaskan umat Islam dari kecenderungan untuk meng-ukhrawi-kannya. Dengan demikian, kesediaan mental untuk selalu menguji dan menguji kembali kebenaran suatu nilai di hadapan kenyataan-kenyataan material, moral, ataupun histories, menjadi sifat kaum muslimin. Sekularisasi dimaksudkan untuk lebih memantapkan tugas duniawi manusia sebagai khalifah Allah SWT di bumi (khalifatullah fil ardli). Fungsi sebagai khalifah memberikan ruang bagi adanya kebebasan manusia untuk menetapkan dan memilih sendiri cara dan tindakan dalam rangka perbaikan hidupnya di atas bumi, dan sekaligus memberikan pembenaran bagi adanya tanggung jawab manusia atas perbuatannya di hadapan Tuhan.

Konsep sekularisasi Madjid, menurut Fachry Ali dan Bahtiar Effendy, dimaksudkan sebagai lembaga yang dapat dipergunakan umat Islam untuk "membedakan", bukan untuk memisahkan persoalan duniawi dan ukhrawi. Dengan kata lain, Nurcholish memberikan penafsiran "baru" mengenai peristilahan tersebut. Sekularisasi dipahami sebagai sarana untuk membumikan ajaran Islam, karena jelas, Nurcholish membuat pembedaan prinsipil antara sekularisasi dan sekularisme. Sekularisme adalah paham tertutup, yakni suatu sistem ideologi yang lepas dari agama, dan inti sekularisme adalah penolakan adanya kehidupan lain di luar kehidupan duniawi ini. Sementara, sekularisasi diartikan sebagai bentuk sosiologis, bukan filosofis, yang lebih banyak mengisyaratkan ke pengertian pembebasan masyarakat dari kehidupan takhyul dan magis. Sekularisasi di sini tidak berarti penghapusan nilai-nilai keagamaan.

Pengertian baru dari pemikiran Nurcholish Madjid tentang sekularisasi ini tampaknya diambil dari Talcott Parsons, Harvey Cox, dan Robert N. Bellah. Karena itulah Nurcholish mengatakan, pengertian sekularisasinya digunakan sebagai istilah sosiologis. Bagi Parsons, istilah itu lebih merujuk ke pengertian "pembebasan" masyarakat dari belenggu takhyul dalam beberapa aspek kehidupan. Ini tidak berarti adanya penghapusan orientasi keagamaan dalam norma-norma dan nilai-nilai kemasyarakatan. Dawam Raharjo mengutip dua pengertian sekularisasi dari kamus sosiologi, yang mengemukakan pengertian berbeda akan tetapi sama-sama menekankan aspek sebagai proses (Pardoyo, 1996). Kamus sosiologi yang disusun oleh Nicholas Abercrombie et. Al., menjelaskan bahwa, "sekularisasi adalah proses di mana pemikiran mengenai praktek dan institusi keagamaan telah kehilangan arti pentingnya." Menurut Fairchild dalam Kamus sosiologi, "sekularisasi adalah suatu proses di mana struktur social yang tadinya tertutup dan suci telah ditransformasikan menjadi suatu bentuk kontol dan interaksi yang bukan suci dan terjangkau”.

Pemikiran Nurcholish mengenai gejala sekularisasi nampaknya merujuk pada pemikiranpemikiran Harvey Cox, dan Robert N. Bellah. Terutama Robert N. Bellah, seorang penganut Weber, yang dalam pandangannya menggunakan istilah sekularisasi dalam konotasi positif. Ia melihat bahwa sebelum terjadinya proses sekularisasi di Eropa, Islam telah memelopori proses sekularisasi di dunia Arab, yaitu dengan ajaran Tauhidnya. Ia mengartikan sekularisasi sebagai the radical devaluation of all existing social structures in the face of this central God-men relationship (devaluasi radikal terhadap struktur sosial yang ada, berhadapan dengan hubungan Tuhan manusia yang sentral (Pardoyo, 1996). Menurut Madjid, sekularisasi memperoleh maknanya yang konkrit dalam desaklarisasi segala sesuatu selain hal-hal yang benar-benar bersifat ilahiah (trasendental), yaitu dunia ini. Dan menghubungkannya dengan konsep tauhid. Menurutnya, hasil langsung dari tauhid ini adalah penolakan atas segala bentuk pemberhalaan: 
”... Sebenarnya, pandangan yang wajar dan menurut apa adanya kepada dunia dan masalahnya, secara otomatis harus dipunyai oleh seorang Muslim, sebagai konsekuensi logis dari tauhid. Pemutlakan trasendensi semata-mata kepada Tuhan, sebenarnya, harus melahirkan desaklarisasi pandangan terhadap selain Tuhan, yaitu dunia dan masalah-masalah serta nilainilai yang bersangkutan dengannnya. Sebab sakralisasi kepada sesuatu selain Tuhan itulah, pada hakikatnya, yang dinamakan syirik, lawan tauhid. Maka, sekularisasi itu sekarang memperoleh maknanya yang konkret, yaitu desaklarisasi terhadap segala sesuatu selain hal-hal yang benar-benar bersifat ilahiah (transendental), yaitu dunia lain” (Madjid, 1987).

Untuk lebih memahami sekularisasi Madjid, pemahaman tersebut perlu dilengkapi dengan sekularisasi Harvey Cox. Cox mengemukakan tiga aspek sekularisasi (Pardoyo, 1996), yaitu: Pertama, pembebasan alam dari ilusi (dissenchantnent of nature); ini dimaksudkan sebagai pembebasan alam dari pengaruh Ilahi; mancakup kepercayaan animistis, dewa-dewa, dan sifat magis dari alam. Dengan demikian, manusia tidak lagi menganggap alam sebagai kesatuan dengan Tuhan. Kedua, desaklarisasi politik (desaclarization of politics), Desaklarisasi politik; maksudnya penghapusan legitimasi kekuasaan/wewenang politik dari agama, yang merupakan persyaratan pembangunan politik, maka jargon, "Islam yes, partai Islam no"? Madjid merupakan suatu keharusan. Ketiga, pembangkangan terhadap nilai-nilai (deconsecration of values). Pembangunan terhadap nilai-nilai; berarti nilai-nilai, termasuk nilai agama, terbuka untuk perubahan yang di dalamnya manusia bebas menciptakan perubahan dan membenamkan dirinya ke dalam proses evolusi.

\section{Pluralisme Agama}

Islam adalah agama yang sangat menjunjung tinggi nilai-nilai pluralitas atau kemajemukan. Pluralitas secara harfiah, berasal dari bahasa Inggris plural yang berarti bentuk jamak atau menunjukkan dalam arti banyak. Pluralitas umat manusia merupakan kenyataan yang dikehendaki Allah (sunnah Allah) yang tak dapat dielakkan lagi, firman-Nya: "Hai manusia, sesungguhnya Kami (Allah) telah menciptakan kamu dari seorang laki-laki dan seorang perempuan dan menjadikan kamu berbangsa-bangsa dan bersuku-suku supaya kamu saling mengenal. Sesungguhnya orang yang paling mulia di antara kamu di sisi Allah ialah orang yang paling bertaqwa di antara kamu. Sesungguhnya Allah Maha Mengetahui lagi Maha Mengenal.” (QS al-Hujurat/49: 13). "Dan di antara tanda-tanda kekuasaan-Nya ialah menciptakan langit dan bumi serta berlain-lainan bahasamu dan warna kulitmu. Sesungguhnya pada yang demikian benar-benar terdapat tanda-tanda bagi orang-orang yang mengetahui." (QS al-Rum/30: 22).

Kedua ayat ini menunjukkan perbedaan manusia dalam suku, bangsa, bahasa, dan warna kulit harus diterima sebagai kenyataan positif yang merupakan tanda kebesaran Tuhan Yang Maha Esa bagi manusia yang memahaminya. Juga terdapat penegasan tentang kemajemukan dalam pandangan dan cara hidup di antara sesama manusia yang tak perlu digusarkan, dan hendaknya dipakai sebagai pangkal tolak untuk berlomba-lomba menuju kebaikan (fastabiqu al-khairat), dan Tuhan Yang Maha Esa-lah yang akan menjelaskan mengapa manusia berbeda-beda, nanti ketika manusia kembali keharibaan-Nya. “... Untuk tiap-tiap umat di antara kamu, kami berikan aturan dan jalan yang terang. Sekiranya Allah menghendaki, niscaya kamu dijadikan-Nya satu umat (saja), tetapi Allah hendak menguji kamu terhadap pemberian-Nya kepadamu, maka berlomba-lombalah berbuat kebaikan. Hanya kepada Allah-lah kembali kamu semuanya, lalu diberitahukan-Nya kepadamu apa yang telah kamu perselisihkan itu” (QS al-Maidah/5: 48).

Seandainya Allah SWT menghendaki kesatuan pandangan dan cara hidup antarsesama manusia, niscaya diciptakan-Nya manusia tanpa akal budi seperti binatang, tumbuhan, atau bendabenda yang tidak bernyawa yang tak memiliki kemampuan memilih, karena hanya dengan demikian seluruhnya akan menjadi satu pendapat. 
Pluralisme dalam pandangan Madjid berangkat dari pemahamannya mengenai hubungan Islam dan pluralisme. Hubungan ini berpijak pada semangat humanitas dan universalitas Islam. Humanitas di sini yakni Islam merupakan agama kemanusiaan (fitrah). Cita-cita Islam sejalan dengan cita-cita kemanusiaan umumnya. Misi Nabi Muhammad untuk mewujudkan rahmat bagi seluruh alam (rahmatan li al-'alamin). Jadi bukan semata-mata untuk menguntungkan komunitas Islam saja.

Ada dua tema utama yang menjadi sorotan Madjid tentang masalah pluralisme, yaitu: pluralisme intern Islam dan pluralisme antar agama atau keyakinan.

\section{Pluralisme Intern Islam}

Pluralisme intern Islam dalam pandangan Madjid, berangkat dari pemahaman tentang Islam (agama formal) dan hubungan dengan para pemeluknya (kaum Muslim) (Madjid, 1992). Sejak periode Madinah, Islam telah terbentuk sebagai komunitas plural yang terdiri dari berbagai kelompok, suku, dan etnis. Pluralitas intern Islam tersebut tidak menyangkut masalah-masalah asasi seperti keimanan dan ketaqwaan, melainkan disebabkan oleh perbedaan latar belakang masing-masing pribadi dan kelompok kalangan umat sejak dahulu. Misalnya, tidak mungkin mengingkari adanya sisa-sisa primordial yang kurang baik seperti faktor keturunan, kedaerahan, dan sosial-budaya lainnya.

Pada saat Nabi Muhammad S. A. W. berada di sekitar para sahabat, ketika terjadi perselisihan di antara mereka, beliau menyelesaikannya berdasarkan petunjuk Allah SWT, dan para sahabat pun menerima dengan legowo, karena Nabi Muhammad S. A. W. diyakini oleh mereka sebagai pemegang otoritas keagamaan (Islam). Namun ketika beliau tiada, tidak ada lagi pemegang otoritas keagamaan (Islam) tersebut, kecuali yang bersumber dari al-Qur'an dan al-Hadits, itupun berdasarkan penafsiran para sahabat berikut ijtihadnya. Maka sisa-sisa primordial itu pun bangkit kembali.

Sejarah membuktikan penyebab pertikaian antara para sahabat Nabi Muhammad S. A. W. tersebut pada awalnya adalah masalah politik, tanpa warna keagamaan. Tetapi lambat laun seperti dijelaskan Madjid, pengelompokan politik mengambil warna keagamaan, dan lahirlah aliran-aliran yang disebabkan oleh perbedaan mereka dalam menafsirkan ajaran agama. Dorongan mencari pembenaran keagamaan bagi pandangan dan praktik politik mereka telah menghasilkan berbagai pemikiran keagamaan yang sering tidak hanya berbeda satu sama lain, malah banyak yang bertentangan (Madjid, 2000), seperti Syi'ah, Umawi, Sunni, Khawarij, Mu'tazilah, Qadariyyah, Jabbariyah, dan yang lainnya. Di lain sisi, dengan keteladan dan perjuangan beberapa sahabat Nabi Muhammad S. A. W., Islam yang segera menyebar ke berbagai wilayah di belahan dunia, menemukan ragam budaya dan lingkungan sosial berbeda dengan kondisi pertama Islam diturunkan, dan Islam menjelma dalam berbagai latar ragam budaya, yang kadang cocok dengan nilai-nilai Islam dan kadang berbeda bahkan bertolak belakang dengan al-Qur'an dan al-Hadits.

Mengantisipasi perbedaan tersebut agar tidak terperangkap dalam pertikaian seperti tersebut di atas, menurut Madjid hendaklah digalang kembali persaudaraan Islam (ukhuwah Islamiyyah). Maka dari tinjauan kemanusiaan biasa, dapatlah dikatakan bahwa ajaran persaudaran berdasarkan iman atau ukhuwah Islamiyyah adalah merupakan antisipasi kepada kemungkinan terjadinya krisis-krisis yang memilukan hati kaum beriman itu. "Ukhuwah Islamiyah adalah sebuah resep untuk mengatasi persoalan yang kini menimpa kaum muslim seluruh dunia. Apalagi di seluruh muka bumi ada bentukbentuk krisis yang melibatkan umat Islam, sejalan dengan kenyataan bahwa Islam adalah agama yang paling pesat dan luas menyebar di antara umat manusia. Dilihat dari sudut pandang ajaran keagamaan, persaudaraan berdasarkan iman adalah sangat sentral, dan tentu tepat sekali jika diyakini sebagai obat mujarab berbagai penyakit umat” (Madjid, 2000). 
Ukhuwah Islamiyyah yang dimaksud Madjid ialah ukhuwah (persaudaraan) yang berdasarkan iman (Madjid, 2000). Persaudaraan ini, dalam pengertian K.H. Ahmad Shiddiq, adalah persaudaraan yang tumbuh dan berkembang karena persamaan keimanan atau tauhid, baik dalam skala nasional atau international (Qomar, 2002). Quraish Shihab mengistilahkannya sebagai ukhuwwah fi din al-Islam (persaudaraan antarsesama muslim) (Shihab, 1998). Allah SWT berfirman: "Seusungguhnya orangorang Mu'min adalah bersaudara, maka karena itu damaikanlah antara kedua saudaramu s dan bertaqwalah kepada Allah agar supaya kamu mendapat rahmati.” (QS al-Hujurat/49: 10-11).

Allah SWT dan Rasul-Nya, Muhammad S. A. W. mensyari'atkan tentang ukhuwah Islamiyyah karena disadari bahwa pada kenyataannya, sifat alamiah manusia berbeda-beda sesuai dengan sunnatullah tersebut. Begitupun dengan Islam rentan sekali dengan perbedaan. Maka persaudaraan berdasarkan iman, menurut Madjid, perlu diletakkan pada proporsinya sesuai dengan ajaran Kitab Suci dan Sunnah Nabi Muhammad S. A. W. Pendapat ini bertitik tolak dari pandangan kurang tepat bahwa seolah-olah ukhuwah Islamiyyah tidak akan terwujud kecuali jika seluruh umat Islam menjadi sama dan satu dalam segala hal alias monolitik (Madjid, 2000). Maka sangat logis bahwa ajaran Allah tentang persaudaraan berdasarkan iman diberikan dalam kerangka kemajemukan (pluralitas), bukan ketunggalan (monolitik). Sebab hukum perbedaan yang ditetapkan Allah untuk manusia juga berlaku pada kalangan kaum iman sendiri. Bagaimanapun, kaum beriman terdiri dari pribadi-pribadi dengan latar belakang biografi, sosial dan budaya berbeda. Perbedaan sesama manusia yang diterima tanpa menimbulkan perselisihan merupakan rahmat Allah yang membawa kebahagiaan, sedangkan yang diterima dengan perselisihan/permusuhan akan menjadi pangkal kesengsaraan.

Untuk melaksanakan dan memelihara ukhuwah Islamiyyah sebagaiman petunjuk Kitab Suci, Madjid memberikan beberapa resep, yaitu: Pertama, hindari sikap absolutistik dengan mengembangkan paham relativitas kebenaran beragama, karena kebenaran sepenuhnya milik Allah SWT. Hal ini berlaku pada masalah agama yang sifatnya sekunder. Perbedaan paham atau tingkah laku dalam hal-hal sekunder dalam Islam betapa pun besarnya, jangan menjadi penyebab perpecahan umat Muslim. Madjid menjelaskan: ”Jadi, menurut petunjuk Ilahi itu, demi prinsip persaudaraan yang amat fundamental itu, hubungan sesama muslim yang berbeda-beda paham atau tingkah laku sekundernya (sedangkan dalam paham dan tingkah laku primer tentu saja harus sama) tidaklah boleh terjadi dalam kerangka sikap absolutistik seperti sikap: "Saya pasti benar dan orang lain pasti salah!" Melainkan harus dalam kerangka sikap yang relativistik, yaitu sikap (seperti banyak dikutip dari Iman Abu Hanifah): "Saya benar, tapi bisa salah; dan orang lain salah tapi bisa benar!” (Madjid, 2002).

Untuk lebih memahami apa yang dimaksud hal-hal yang sifatnya sekunder, Quraish Shihab menjelaskan dalam tiga kategori yaitu: Pertama, konsep tanawwu' al-'ibadah (keragaman cara beribadah), konsep ini, mengakui adanya keragaman yang dipraktikkan oleh Nabi Muhammad S. A. W. dalam bidang pengalaman keagamaan, yang mengantarkan kepada pengakuan akan kebenaran semua praktek keagamaan, selama semuanya merujuk pada Nabi Muhammad S. A. W.. Kedua, konsep al-mukhti'u fi al-ijtihad lahu ajr (yang salah dalam berijtihad pun [menetapkan hukum] mendapat ganjaran), ini berarti bahwa selama seseorang mengikuti pendapat seorang ulama, dia tidak akan berdosa, bahkan tetap diberi ganjaran oleh Allah SWT, walaupun hasil ijtihad yang diamalkannya keliru. Hanya saja perlu dicatat bahwa penentuan yang benar dan salah bukan wewenang makhluk, tetapi wewenang Allah SWT, yang baru akan diketahui di hari kemudian. Ketiga, konsep la hukma lillah qabla ijtihad al-mujtahid (Allah belum menetapkan suatu hukum sebelum upaya ijtihad dilakukan oleh seorang mujtahid), ini berarti hasil ijtihad itulah hukum Allah bagi masing-masing mujtahid, walaupun hasil ijtihadnya berbeda-beda (Madjid, 2002).

Sikap tersebut pun harus tetap dipertahankan dalam berinteraksi teologis dengan sesama kaum Muslim. Menurut Madjid harus menyimpan dalam hati sifat keraguan sehat (healthy skepticism), yaitu sikap cadangan dalam pikiran dan siap sedia mengakui kebenaran orang lain jika memang ternyata benar dan mengakui kesalahan diri sendiri jika memang ternyata salah. Madjid menjelaskan: 
"Dalam berinteraksi “ideologis” sesama Muslim, kita harus menyimpan dalam hati kita sikap "keraguan yang sehat” (healthy skepticism), yaitu sikap cadangan dalam pikiran dan siap sedia mengakui kebenaran orang lain jika memang ternyata benar dan mengakui kesalahan diri sendiri jika memang ternyata salah. Tentu hal itu bukanlah perkara mudah, karena memerlukan tingkat ketulusan dan kejujuran yang sangat tinggi, sementara kita rata-rata cenderung dikuasai oleh hawa nafsu untuk merasa benar dan ...merasa menang (sendiri)!” (Madjid, 2002).

Adapun dalam hal-hal yang sifatnya primer itu harus sama, seperti keyakinan terhadap Keesaan Tuhan dan kerasulan Muhammad, al-Qur'an, dan yang lainnya, mesti sama. Untuk hal-hal yang bersifat skunder menurutnya kebenarannya bersifat relatif, sedangkan yang primer adalah mutlak (absolut).

Kedua, harus bersikap terbuka antarsesama Muslim, betapa pun besarnya perbedaan baik dalam paham maupun tingkah laku jangan sampai menjadikan kaum Muslim terpecah. Madjid menjelaskan: "Dengan begitu ukhuwah Islamiyah sebenarnya menghendaki sikap-sikap terbuka antara sesama muslim, sebagaimana semangat itu ditunjukkan dengan baik sekali oleh kaum Salaf. Sedangkan sikap tertutup adalah musuh utama prinsip ukhuwwah” (Madjid, 2002). Karena itu setiap kaum Muslim wajib bersikap terbuka dan toleransi (al-tasamuh) antarsesamanya, demi terciptanya ukhuwwah Islamiyyah, dan sikap tertutup harus dihindari. Ketiga, selain kedua sikap tersebut, Madjid menganjurkan agar kaum Muslim menghayati dan melaksanakan seruan Tuhan dalam QS alHujurat/49: 11-12, yaitu: jangan mengolok-olokkan, jangan mencela, jangan memanggil dengan panggilan yang buruk, jauhilah berprasangka buruk, jangan mencari-cari kesalahan, dan jangan menggunjing (desas desus) antara satu Muslim dengan Muslim lainnya. Secara lengkap bisa dilihat di bawah ini, yaitu:

"Hai orang-orang yang beriman, janganlah suatu kaum mengolok-olokkan kaum yang lain, (karena) boleh jadi mereka (yang diolok-olokkan) itu lebih baik dari mereka (yang mengolok-olokkan); dan jangan wanita-wanita (mengolok-olokkan) wanita-wanita lain, (karena) boleh jadi wanita-wanita (yang diperolok-olokkan) lebih baik dari wanita-wanita (yang mengolok-olokkan), dan janganlah kamu mencela dirimu sendiri, dan janganlah kamu panggil memanggil dengan gelar-gelar yang buruk. Seburuk-buruk panggilan ialah (panggilan) yang buruk sesudah iman, dan barang siapa yang tidak bertaubat, maka mereka itulah orangorang yang zalim." "Hai orang-orang yang beriman, jauhilah kebanyakan dari prasangka, sesungguhnya sebagian dari prasangka itu adalah dosa, dan janganlah kamu mencari-cari kesalahan orang lain, dan janganlah sebahagian kamu menggunjung sebahagian yang lain. Sukakah salah seorang di antara kamu memakan daging saudaranya yang sudah mati! Maka tentulah kamu merasa jijik kepadanya. Dan bertakwalah kepada Allah. Sesungguhnya Allah Maha Penerima taubat lagi Maha Penyayang.” (QS al-Hujurat/49: 11-12).

Dengan memelihara ketiga sikap tersebut, Madjid mengharapkan kaum Muslim tetap menjaga tegaknya ukhuwah Islamiyah di kalangan mereka secara nyata, bukan hanya sebagai slogan belaka, tetapi sebuah realitas kehidupan, tanpa mengorbankan kreativitas dan pluralitas yang pada mereka.

\section{Pluralitas Antar agama}

Perbedaan agama atau keyakinan sekalipun jangan dijadikan batu sandungan untuk mewujudkan rahmat bagi seluruh alam (rahmatan li al-alamin). Islam mengajarkan pada kaum Muslim untuk mengakui eksistensi agama-agama lain. Tuhan menunjukkan, bahwa orang-orang Mu'min, Yahudi, Nashrani, dan Shabi'in, asalkan mereka benar-benar beriman kepada Allah dan Hari Akhir serta beramal shaleh, mereka akan memperoleh kebahagian (Lihat QS al-Baqarah/2: 62). Dalam ayat lain dijelaskan, bahwa kaum muslim dilarang memaki sembahan-sembahan mereka, karena mereka akan membalas makian tersebut kepada sembahan kaum Muslim (Allah SWT) (Lihat QS al-An'am/6: 108). Pengakuan eksistensi terhadap agama-agama lain bagi Madjid dengan memperluas pemaknaan Ahl al-Kitab dengan cakupan yang lebih luas, tidak hanya Yahudi dan Nashrani, tetapi juga Hindu, Budha, atau yang lainnya. Dia menjelaskan dengan mengutip pendapat Abdul Hamid Hakim, tokoh pembaharu dari Padang Panjang, Sumatra Barat, yaitu: 
"Pengertian Ahl al-Kitab tidak hanya orang Yahudi dan Kristen kemudian Majusi saja, melainkan orang Hindu, Budha, para penganut agama Cina, Jepang, dan lain-lain. Karena menurut Abdul Hamid Hakim, mereka itu penganut suatu jenis kitab suci yang memuat ajaran dasar tauhid atau Ketuhanan Yang Maha Esa, sampai sekarang. Memang benar bahwa mereka kemudian menyimpang dari tauhid itu, dan terjadi perubahan dalam bagian-bagian tertentu kitab suci mereka, namun Abdul Hamid Hakim mengisyaratkan hal itu tidak perlu mengherankan, sebab hal serupa juga terjadi pada kaum Yahudi dan Kristen, padahal munculnya agama-agama ini lebih kemudian daripada agama-agama India dan Cina itu” (Madjid dalam Effendy [ed.], 1999; Rasyid, 1993).

“Zoraster itu nabi, Budha Gautama itu nabi, Lao Tze itu nabi, dan Kung Fu Tze itu juga nabi. Sebab al-Qur'an sendiri mengatakan: wa laqad ba'atsna fi kulli ummatin rasulan, sungguh telah Kami bangkitkan untuk setiap umat seorang rasul” (Madjid dalam Sukidi, 2001).

Pandang Madjid tersebut, didasarkan pada al-Qur’an yang menyatakan bahwa Tuhan telah mengutus rasul-rasul-Nya kepada tiap-tiap bangsa (Lihat QS Yunus/10: 47). Selanjutnya juga dijelaskan bahwa di antara rasul-rasul tersebut ada yang diceritakan oleh Allah dan ada pula yang tidak (Lihat QS al-Mu'min/40; 78 dan al-Nisa'/4; 164). Penyebutan agama Yahudi, Kristen, Shabiin, dan Majusi dalam al-Qur'an, karena bangsa Arab telah mengenalnya, sedangkan agama-agama India dan Cina, bangsa Arab belum mengenalnya, sehingga tidak perlu membuat keterangan yang terasa asing (ighrab) dengan menyebut golongan yang tidak dikenal oleh orang yang menjadi addres pembicaraan itu di masa turunnya al-Qur'an (Madjid, 1995). Selain pengakuan atas eksistensi agama lain, Islam juga mengajarkan, “Tidak boleh ada paksaan dalam agama”, (QS al-Baqarah/2: 265). Dari sini dapat dipahami adanya pandangan yang berbeda dengan agamanya, karena semuanya tak mungkin berada di luar Kehendak Ilahi. Allah SWT menjelaskan, bahwa jika Allah menghendaki tentulah manusia di bumi seluruhnya beriman kepada-Nya, tetapi itu tidak dikehendaki-Nya.

"Dan jikalau Tuhannya menghendaki, tentulah beriman semua orang yang ada di muka bumi seluruhnya. Maka apakah kamu hendak memaksa manusia supaya mereka menjadi orang-orang yang beriman semuanya”? (QS Yunus/10: 99).

Selain dari nash al-Qur'an yang dijadikan alasan (hujjah) dalam perbedaan agama atau keyakinan tersebut, bagi Madjid tidak dibolehkan memaksakan agama karena pada dasarnya ajaran seperti ini (yang tidak dipaksakan merupakan pemenuhan alam manusia yang secara pasti telah diberi kebebasan oleh Allah; sehingga pertumbuhan perwujudannya bersifat dari dalam, tidak tumbuh apalagi dipaksakan - dari luar. Sikap keagamaan hasil paksaan dari luar tidak otentik karena kehilangan dimensinya yang paling mendasar dan mendalam, yaitu kemurnian atau keikhlashan (Madjid, 1992). Dalam bahasa Thabathaba'i, hal ini karena agama merupakan rangkaian ilmiyyah (keilmuan) yang diikuti oleh amaliyyah (perwujudan perilaku) dan menjadi satu kesatuan i'tiqadiyyah (keyakinan) yang merupakan persoalan hati, maka bagaimanapun agama tidak bisa dipaksakan oleh siapapun (Usman, 2002).

Selain itu, Tuhan juga mengganggap manusia sudah mampu dan harus diberi kebebasan untuk membedakan dan memilih sendiri mana yang benar dan mana yang salah. Dalam bahasa Madjid diistilahkan, Tuhan menggap manusia sudah dewasa dan dapat menentukan sendiri jalan hidupnya yang benar. Madjid menjelaskan:

”Oleh karena Tuhan telah percaya kepada kemampuan manusia, maka Dia tidak lagi mengirimkan utusan atau rasul untuk mengajari mereka tentang kebenaran. Deretan para nabi dan rasul telah ditutup dengan kedatangan Nabi Muhammad S. A. W. Sebagai Rasul penutup, Nabi Muhammad S. A. W. membawa dasar-dasar pokok ajaran yang terus dapat dikembangkan untuk segala zaman dan tempat. Maka sekarang terserah kepada manusia yang telah "dewasa” untuk secara kreatif menangkap pesan dalam pokok ajaran Nabi Penutup itu dan memfungsikannya dalam hidup nyata mereka” (Madjid, 2002). 
Keistimewaan ini, menurut Madjid, karena manusia memiliki yang istimewa pula, yaitu sesuatu dari Ruh Tuhan, sehingga manusia mempunyai kesadaran penuh dan kemampuan untuk memilih (Madjid, 2002). Maka dari itu, prinsip kebebasan agama adalah penghargaan manusia dari Tuhan, karena Tuhan mengakui hak manusia untuk memilih sendiri jalan hidupnya. Sebagai konsekuensinya manusia bertanggung jawab atas pilihannya tersebut.

Karena hal-hal tersebut, maka tidak berlebihan jika dikatakan bahwa semua agama pada intinya sama dan satu, yang dalam pandangan Madjid didasarkan pada kesatuan kenabian dan kesatuan pesannya. Tetapi perlu disadari manifestasi sosio-kulturalnya secara historis berbeda-beda. Madjid menghendaki sejalan dengan semangat al-Quran agar fenomena lahiriah ini tidak menghalangi usaha menuju titik temu (kalimatun sawa', common plat form) antara semuanya. Dan jika pun rumusan linguistik dan verbal keyakinan keagamaan itu berbeda-beda, dapat dipastikan bahwa eksternalisasi keimanan dalam dimensi kemanusiaan sama, karena menyangkut kerja nyata (Ruslani dalam Sukandi (Ed.), 2001). Maka al-Islam sendiri, menurut Nabi Muhammad paling baik dinyatakan dalam aktivitas kemanusiaan seperti menolong kaum miskin, dan dalam mengusahakan perdamaian kepada semua orang tanpa kecuali.

\section{SIMPULAN}

Secara umum, pemikiran teologi (Islam) inkusif Cak Nur bermula pada pemahaman kepada Islam. Intinya bahwa seluruh risalah samawi yang diturunkan disebut Islam yang dalam arti umumnya berarti penyerahan diri secara sempurna atau ketundukkan penuh kepada perintah-perintah Allah. Sementara Islam yang digunakan dalam makna spesifik mengacu kepada versi Islam terakhir yang dibawa oleh Nabi Muhammad S. A. W. Namun, dalam keyakinan Cak Nur, Islam yang diwahyukan kepada Muhammad S. A. W. adalah yang terbaik. Teologi (Islam) inklusif yang dimaksud adalah pemahaman atau wawasan keislaman yang terbuka, luwes, dan toleran. Terbuka memiliki makna bahwa Islam memberikan peluang kepada manusia untuk mengkritisinya, jika kebenaran atau hikmah yang disampaikan tersebut, maka seorang muslim harus berlapang dada menerimanya, walau dari siapa atau apa pun datangnya. Luwes bermakna mau berhubungan dengan pihak lain, tanpa rasa canggung, dan juga tanpa melihat perbedaan, baik agama, kepercayaan, maupun asal-usul. Toleran bermakna menghormati perbedaan, baik dengan yang seagama atau sekeyakinan maupun dengan yang berbeda agama atau keyakinan. Pemahaman yang demikian bertolak dari nilai-nilai dasar Islam, dengan ide yang utama "Islam sebagai ajaran kasih sayang untuk dunia" (rahmatan lil 'alamin). Implikasi dari teologi (Islam) inklusif adalah keberanian membongkar selubung kusam dunia penghayatan Islam yang bercorak doctrinal-dogmatis. Teologi (Islam) Inklusif lebih menekankan nilai-nilai dasar Islam, bukan kepada simbol-simbol belaka. Penekanan yang berlebihan atau keterjebakan terhadap simbol-simbol keagamaan justru mengandung bahaya kontraksi, distorsi, dan reduksi ajaran agama itu sendiri. Semangat penekanan terhadap simbol-simbol agama tersebut sering sekali tidak sesuai dengan substansi ajaran agama itu sendiri.

Berdasarkan data dan analisis yang telah dipaparkan telah ditelaah gagasan-gagasan teologi (Islam) inklusif yang dikemukakan Nurcholish Madjid. Dari penelitian tersebut dapat penulis simpulkan dalam tiga bidang kajian, yaitu keagamaan, politik, dan kebudayaan. Dalam bidang hubungan antar-agama ada tiga konsep yang menyertainya, yaitu eksklusivisme, inklusivisme, dan paralelisme (pluralisme). Dari ketiga konsep ini, Cak Nur mengikuti alur pemikiran yang kedua, yaitu inklusivisme. Bagi Madjid, inklusivisme sebenarnya berpijak pada semangat humanitas dan universalitas Islam. Humanitas Islam yang dimaksud yakni Islam merupakan agama kemanusiaan, cita-cita Islam sejalan dengan cita-cita kemanusiaan umumnya, dan kerasulan Muhammad S. A. W. untuk membawa rahmat bagi semesta (rahmatan li al-'alamin), terutama manusia. Sedangkan universalitas Islam, secara teologis dapat dilacak dari perkataan al-islam, yang berarti sikap pasrah, tunduk, dan patuh pada Tuhan. Semua agama yang benar pasti mengacu pada penyerahan diri, ketundukan, dan kepatuhan pada Tuhan atau al-islam. 
Dalam bidang politik, Cak Nur tidak mengharapkan negeri plural Indonesia, berdiri negara yang semata-mata berdasarkan Syari'at Islam. Justru yang urgent ialah memperjuangkan nilai-nilai ke-Islam-an, seperti keadilan, musyawarah, persamaan hak, dan lainnya dalam kehidupan berbangsa dan bernegara. Perjuangan mendirikan negara Islam hanya akan membuat bangsa ini terpecah-belah ke arah kehancuran. Bagi Madjid, sistem politik yang sebaiknya diterapkan di Indonesia yakni sistem yang tidak hanya baik kaum Muslim, tetapi yang sekiranya juga akan membawa kebaikan untuk semua anggota masyarakat Indonesia. Jargon Madjid tentang "Islam yes, partai Islam no"? Adalah sebuah respon politik terhadap kegagalan partai-partai Islam, selain itu adanya kecenderungan mengidentifikasi Islam dengan partai Islam. Karena itu, dalam kehidupan berbangsa dan bernegara Madjid menyetujui Pancasila sebagai kalimatum sawa', cammon platform antarberbagai kelompok. Ini berarti terbuka lebar kesempatan untuk semua kelompok sosial guna mengambil bagian secara positif dalam pelaksanaan kehidupan berpolitik.

Dalam bidang sosial-budaya, Cak Nur melihat bahwa sejak zaman Nabi Muhammad S. A. W. Islam terbentuk oleh latar sosial-budaya yang mengitarinya.Begitu juga Islam yang di Indonesia tak dapat mengabaikan diri dari latar sosial-budaya yang ada. Bagi Madjid, meskipun kebenaran Islam universal, namun acapkali tampil dalam penampakan lahiriah yang berbeda dari masa ke masa dan dari tempat ke tempat. Ini dapat diterangkan dari berbagai aspek, salah satunya adalah persoalan bahasa dalam pengertian seluas-luasnya, termasuk bahasa kultural. Oleh karena itu, kebenaran Islam universal memiliki kemampuan untuk beradaptasi pada lingkungan budaya di mana ia berkembang, secara otentik (setia kepada azasnya sendiri) dan kreatif (termasuk juga kritis). Menjadi kepentingan kaum Muslim di Asia Tenggara, khususnya di negeri tercinta Indonesia ini untuk mewujudnyatakan ajaran-ajaran universal itu begitu rupa sehingga membawa rahmat bagi semua, tidak saja kaum Muslim tetapi juga non-Muslim. Wa Allahu a'lamu bi al-shawab.

\section{DAFTAR PUSTAKA}

Abu Zayd, N. H. A. (2003). al-Qur'an, Hermeneutik, dan Kekuasaan: Kontroversi dan Penggugatan Hermeneutic al-Qur'an, Dede Iswadi, Jajang A. Rohmana, dan Ali Mursyid (penterj.), Bandung: RQiS [Risearch for Quranic Studies].

Barton, G. (1999). Gagasan Islam Liberal di Indonesia, Pemikiran Neo-Modenisme Nurcholish Madjid, Djohan Effendi, Ahmad Wahib, dan Abdurrahman Wahid, Nanang Tahqiq (penterj.), Jakarta: Paramadina.

Dale, C. J. P. 21 Juni, (2002). Mencari Kriteria Kebenaran Religius Lintas Agama. Kompas.

Departemen Agama Republik Indonesia. (1990). Al-Qur'an dan Terjemahnya. Medinah Munawwarah: Mujamma' Khadim al-Haramain al-Syarifain al-Malik Fahd li Thiba'at al-Mushhaf al-Syarif.

Dewan RedaksI EnsIklopedI Islam. (1994). Ensiklopedi Islam, Jakarta: Ichtiar Baru van Hoeve.

Malik, D. D., Idi, S. I. (1988) Zaman Baru Islam Indonesia, Pemikiran dan Aksi Politik Abdurrahman Wahid, M. Amin Rais, Nuecholish Madjid, dan Jalalyddin Rakhmat, Bandung: Zaman Wacana Mulia.

Madjid, N. (1999). Beberapa Renungan Kehidupan Keagamaan untuk Generasi Mendatang. Dalam Effendy (Ed.), Dekontruksi Islam Madzhab Ciputat. Bandung: Zaman Wacana Mulia.

(1995). Islam Agama Kemanusiaan, Membangun Tradisi dan Visi Baru Islam Indonesia. Jakarta: Paramadina. 
(1992). Islam Doktrin dan Peradaban, Sebuah Telaah Kritis tentang Masalah Keimanan, Kemanusiaan, dan Kemodernan. Jakarta: Paramadina.

. (1987). Islam Kemodernan dan Keindonesiaan, Bandung: Mizan, 1987.

(1994). Khazanah Intelektual Islam, Jakarta: Bulan Bintang.

(2000). Masyarakat Religius, Membumikan Nilai-nilai Islam dalam Kehidupan Masyarakat. Jakarta: Paramadina.

. (2002). Pintu-pintu Menuju Tuhan. Jakarta: Paramadina.

. (2001). Sekapur Sirih. Dalam Sukidi (Ed), Teologi Inklusif Cak Nur. Jakarta: Kompas.

(1996). Sekapur Sirih. Dalam Pardoyo (Ed), Sekularisasi dalam Polemik. Bandung: Pustaka Utama Grafiti dan Remaja Rosdakarya Offset.

. (1997). Tradisi Islam, Peran dan Fungsinya dalam Pembangunan Indonesia. Jakarta: Paramadina.

Munawar-Rachman, B. (2001) Islam Pluralis, Wacana Kesetaraan Kaum Beriman. Dalam Sukidi (Ed.). Jakarta: Paramadina.

(1999). Resolusi Konflik Agama dan Masalah Klaim Kebenaran. Dalam Kartika \& Mahendra (Ed.), Dari Keseragaman Menuju Keberagaman, Wacana Multikultural dalam Media. Jakarta: LSPP.

Pardoyo (1996). Sekularisasi dalam Polemik. Bandung: Pustaka Utama Grafiti dan Remaja Rosdakarya Offset.

Priyanto, S. (2001). Wilhelm Dilthey, Peletak Dasar Ilmu-ilmu Humaniora. Semarang: Bendera.

Rasyid, D. (1993). “Pembaharuan” Islam dan Orientalisme dalam Sorotan. Jakarta: Usamah Press.

Shihab, M. Q. (1998). Wawasan al-Qur'an, Tafsir Maudhu'i atas Pelbagai Persoalan Umat, Bandung: Mizan.

Sukandi A. K. (Ed.). (2003). Prof. Dr. Nurcholish Madjid, Jejak Pemikiran dari Pembaharu sampai Guru Bangsa. (Yogyakarta: Pustaka Pelajar.

Sukidi. (2001). Teologi Inklusif Cak Nur. Jakarta: Kompas.

Suriasumantri, J. S. (1987). Ilmu dalam Perspektif. Jakarta: Gramedia.

Tim Penulis Rosda. (1995). Kamus Filsafat. Bandung: Remaja Rosdakarya.

Usman, F. (2002). Wahdat al-Adyan, Dialog Pluralisme Agama. Yogyakarta: LKiS.

Qamar, M. (2002). NU "Liberal", dari Tradisionalisme Ahlussunah ke Universalisme Islam. Bandung: Mizan. 